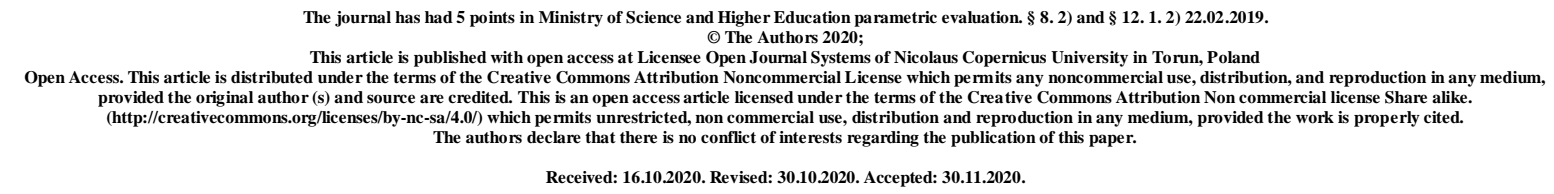

UDK:929[613:002.2] «1918/1919»

\title{
ARSEN RICHYNSKY "HYGIENE COURSE OF HEALTH SCIENCES": HISTORY OF THE PUBLICATION AND MAIN IDEAS
}

\author{
Olena Kravchuk
}

\section{Horbachevsky Ternopil National Medical University}

Teacher of Department of Higher Education Pedagogy and Social Sciences

ORCID 0000-0002-0227-7260

kravchuk.or77@gmail.com

\begin{abstract}
The article analyzes the work of the well-known socio-political, cultural and educational figure of Ukraine of the first half of the XX century, Arsen Richynsky "Hygiene course of health science", which has not lost its relevance today. The issue of organization of hygienic education and training of students in Ukrainian schools and gymnasiums of the times of the Ukrainian People's Republic of 1917-1920 is considered. Little-known milestones of the author's biography related to the writing of this book are revealed.
\end{abstract}

Keywords: Arsen Richynsky; Ukrainian People's Republic; textbook; education; education; teaching; hygiene.

Formulation of the problem. The scientific novelty of the publication is that, despite the rather significant creative heritage of A. Richynsky, the work "Hygiene course of health 
science" has not lost its practical significance, but holistically and systematically not analyzed and studied by scientists. It is worth noting that it has appeared today the need to analyze it objectively and impartially, which will make it possible to understand and reveal the process of writing and printing, use the scientific material of the textbook, more fully explore the biographical data of its author.

The aim of the study - to analyze the work of A. Richynsky "Hygiene course of health science" through the prism of history and modernity, to explore the history of the publication of this work, to reveal little-known milestones in the author's biography associated with its writing.

Analysis of recent research. In the latter decade, the attention of domestic scientists to the figure of Arsen Richynsky. A. Richynsky's activity and views were covered in the publications of modern scientists A. Kolodny, A. Hudyma, N. Stokolos, L. Mykhalchuk, O. Sagan, P. Kraliuk, A. Pisotsky, O. Alyoshina. Despite the interest of researchers in the study of A. Richynsky as a person, socio-political and cultural figure, outside of research remained his work "Course of Hygiene Science of Health", voluminous and extremely rich in ideas, the analysis of which is partially covered in the publications of such modern scientists like Petro Mazur and Mykhailo Andreichyn.

Presentation of the main material. Arsen Richynsky belongs to the figures of the XX century that have left a noticeable mark in Ukrainian history. Its versatility is impressive a practitioner, publicist, editor, publisher, historian, ethnographer, composer, a recognized ideologue of Ukrainian Orthodoxy. Despite this, it was forgotten for a long time and only with Ukraine's independence did it take its rightful place in its cultural space.

Arsen Richynsky was born on June 25, 1892 in the village of Tetylkivtsi, Kremenets County, Volyn Province. Today this village belongs to the Shumsky district of the Ternopil region. He received his primary education at the village church-parish school, then at the Kremenets Theological College, Zhytomyr Theological Seminary, after which in 1911 he became a teacher at the church-parish school in the village of Sidnyarky, Lutsk County. In the autumn of 1911, Arsen Richynski entered the medical faculty of the University of Warsaw, and at the beginning of the First World War he transferred to St. Volodymyr's University in Kyiv.

After graduating from the university from May 1917 to April 1920 he served as a doctor at the Izyaslav County Hospital. In 1917, A. Richynsky was elected chairman of the Izyaslav County Zemstvo, a local self-government body. He was later appointed a member of the school board of the county council. A. Richynsky becomes an active public figure of the city. 
He was engaged in publishing, in particular, edited the magazine "New Roads", was a regular lecturer at Ukrainian studies courses for teachers in Ostroh.

Arsen Richynsky understood that with the development of Ukrainian schooling, during the establishment of Ukrainian statehood in 1917-1920, only the training of new teachers is insufficient, which should be added to the development of Ukrainian textbooks. He wrote: "Due to the long-term national and cultural oppression of Ukrainian literature during the strengthening of our national liberation movement, it found itself in a rather difficult situation - mainly due to technical difficulties associated with intensive supply of Ukrainian textbooks to the general public."

A. Richynsky in his activity skillfully and professionally combined active socialpolitical, cultural-educational work with writing books. In parallel with his medical work, he taught hygiene at the Izyaslav Higher Primary School. Working as a teacher, teaching the subject of hygiene, Richynsky faced the problem of lack of a Ukrainian textbook. To rectify the situation, he developed and submitted to the editorial office of the newspaper "New Road" a manuscript of his lectures on hygiene, which were published as a textbook in two parts. This book was printed as an appendix to the issues of the bulletin of the Izyaslav County People's Council "Nova Doroga", whose editor-in-chief was Richynsky.

In the preface to his book, he noted: "When I had to teach hygiene at Izyaslav Higher Primary School, due to the lack of a textbook I had to give children only lecture notes that they had to rewrite at home. Of course, when the class consists of several dozen students can't help but slow down the whole thing, and at the same time I came up with the idea to revise, supplement and publish my lectures for general use ... So I gave these lectures to Novaya Doroga - almost unprocessed and not even verified by scientific sources, for all this was written from memory, since my library of the unfortunate 1915 was taken to the other side of the Dnieper" [1].

During the First World War, Richynsky was repeatedly forced to evacuate during the hostilities. During the first move in 1915 to the village of Vasylivka, Petrovsky district, Saratov province, he took with him the most valuable, including his library. Then, in connection with the war, he was forced to move to other villages, but he did not always have the opportunity to carry the library with him, it was lost [2].

As a doctor by profession, he worked on materials for a textbook on hygiene, which he adapted to the program of 7-8 grades of gymnasiums approved by the Ministry of Education in September 1906. The textbook with the author's foreword was published in Izyaslav in two parts: the first was printed in Z. Trachtenberg's printing house in July 1918 [1]. The second 
part was published in the printing house of P. Kirchyk in August 1918 [3]. "Materials for the teaching of hygiene: the science of health in the middle grades of high schools and upper primary schools" is the full title of the book.

The two parts of the textbook covered important topics for life and health, the paragraphs were meaningful and revealed a wide meaning, contained not only theoretical text but also clarity. According to Richynsky, he wrote the materials for the textbook from memory, from the knowledge he gained at the medical university and working as a practicing doctor, which shows that the author was a very intelligent, well-read man, endowed with encyclopedic knowledge. Richynsky wrote: "I hope that my book will be useful not only for schoolchildren, but also for those dark, deaf corners of my native land, where all sorts of superstitions are still so firmly entrenched ... where the people have no idea how to fight the epidemic, and how take care of your health in general" [1].

Later, Richynsky combined two parts of hygiene materials and republished them in one textbook. As the author noted on February 3, 1919 in the preface to this textbook, the publication of the book was delayed for six months and this allowed him to make corrections, add new material. The initial materials were so meaningfully organized and improved that a general biological "Hygiene Course" was involuntarily created. Due to technical difficulties, unfortunately for the author, the drawings could not be added to the publication. The textbook was published in February 1919 with a circulation of 700 copies entitled "Hygiene course in Health science" adapted to the program of VII-VIII grades of gymnasiums. The textbook was quite thorough - 379 pages, it combined the first part, which consisted of thirteen paragraphs, and the second of seventeen paragraphs. The first supplemented part of the book was subtitled "Hygiene Tasks", and the following content: Our enemies in nature. Bacterial physiology; The role of bacteria in a man's life; How the infection is transmitted from a patient to a healthy person and in what ways it enters a healthy body; The body's fight against infection; Invulnerability; Disinfection; A brief overview of infectious diseases; Infectious diseases of the abdomen; More about infectious diseases; Vermin; Social order and human nature; Old age [4].

The textbook covers the task of hygiene in protecting the population from infectious diseases. At that time, in Russia, which included most of Ukraine, 6.5 times more people died from acute infectious diseases than in Switzerland, and three times more than in Austria. According to the author, the emergence of such a situation was greatly facilitated by "neglect at school of science and hygiene, the science of human health" [4]. 
In the following paragraphs of the book at the then level of knowledge summarizes the morphology and physiology of bacteria, the protective value of spores, the evolution of the microbial world. The sources of infection, ways and means of spreading the infection, the susceptibility of the human body to various pathogens are listed and explained. The transmission of the pathogen from a sick person to a healthy one is described in detail. The useful role of most bacteria in human, plant and animal life is given. It is reasonably stated that the living world cannot exist without microorganisms. The historical significance of the scientific discoveries of Anthony Levenguk, Louis Pasteur, Joseph Lister, Robert Koch, and Ilya Mechnikov is very briefly pointed out.

The book quite accurately describes the duration of the incubation period for various infectious diseases, ie the time from the moment of infection to the appearance of the first clinical signs of the disease. It is emphasized that this period is important in combating the spread of infectious diseases, quarantine is described as an effective measure against the spread of epidemics.

A separate section discusses acquired immunity to infections due to illness or vaccination. The smallpox vaccination proposed by the English physician Edward Jenner is described. The author calls these vaccinations "accurate and very necessary."The textbook also writes about vaccines against rabies, plague, cholera, typhoid, serum from diphtheria, meningitis, dysentery, tetanus, scarlet fever and more. The vaccination against rabies proposed by L. Pasteur, which saved the lives of thousands of rabies-stricken animals, is understandable and interesting. The main means of disinfection of that time are listed. The method of disinfection of the apartment where the sick person was described is described. The most important sanitary rules of water supply and nutrition, bases of individual nonspecific prevention of infectious diseases are given in an intelligible form. The author rightly notes that the state should deal with the fight against epidemics and care of infectious patients. The following sections successfully describe the clinical picture of diphtheria, lobar pneumonia, tuberculosis, syphilis, gonorrhea, trachoma, dysentery, cholera, typhoid fever, typhus [5].

The second improved part of the textbook "Special Physiology and Hygiene" is as follows: General view of human nature; The value of skin and skin care; Clothes; Dwelling; Opal; Airing; Sunlight in the life of nature and man; Artificial light; Soil condition and destruction left; Digestion; Food; Water supply; Anatomy and physiology of respiration; Respiratory engine; Atmosphere; Physical labor; Child hygiene; Typos [4].

In the first paragraph of the section "General view of human nature" the author describes the development of land, plants, animals and man according to geology and 
paleontology; development of the human embryo according to embryology from a single cell to an adult organism and the chemical composition and vital functions of the protoplasm.

In the second paragraph, "The importance of skin and its care" Richinsky describes in detail the three layers of skin and the mechanism of tanning; the structure and importance of hair and its care; mechanism of formation and significance of sebaceous and sweat glands. Then we talk about washing the body in the bath, bathing in the pond hardening of the body and first aid for injuries, burns and frostbite.

The textbook also describes the position of the soil and the rules of waste disposal, the chemical composition of the soil and its microbial flora, the arrangement of the sewer and the rules of burial of the dead. The paragraph "Opal" describes the hygienic conditions of good heating and heat capacity of fuel. Here is information about carbon monoxide and emergency care in case of poisoning. The importance of ventilation and sunlight for the life of nature and man is highlighted. The section "Artificial light" describes the hygienic conditions of artificial lighting with candles, kerosene lamps, lighting and water gas, electricity [5].

A. Richynsky in his book also presents the rules of food storage, the importance for human nutrition of animal and plant foods, various spices, types and properties of alcoholic beverages. He notes: "The constant abuse of alcohol and the daily consumption of vodka, even in small quantities, eventually lead to a chronic form of alcohol poisoning, known as alcoholism, which manifests itself in various mental and physical signs of degeneration. ... Thus, the use of alcoholic beverages should be considered useless and harmful" [4].

The following paragraphs of the manual cover the importance of water and the characteristics of water supply, the chemical composition of the atmosphere, the importance of physical labor in human life and childhood hygiene. It should be noted that the complex of respiratory gymnastics, which is presented by the author, is useful to use today in children of different ages. The author also covers the issues of care for teeth and gums, the causes of scurvy and its prevention, constipation and diarrhea and their care, first aid for colds, methods to stop bleeding, the dangers of smoking. Recommendations are given on the timing of isolation of schoolchildren with scarlet fever, measles, rubella, chickenpox, whooping cough, mumps, diphtheria and smallpox.

The textbook contains many citations and references to various scientific sources, in addition to the theory contains tables, statistics and comparative data. The author concludes the foreword to the textbook with the following words: - where the people have no idea how to protect themselves from them and how to take care of their health, their most precious wealth. I also believe that the national Ukrainian idea will not die, but will flourish with new 
force, and in this majestic symphony of our revival, my little work will not remain fruitless "[4].

Directly related to school education, Arsen Richynsky paid much attention to the problems that arose in the then system of school education and training. In his textbook "Health Science Hygiene Course" he presented a number of interesting ideas for improving the educational process. He noted that the general public in Ukraine does not fully understand the importance of education and that "the intelligentsia does not notice the abnormal direction of our school." He argued that "three fundamental flaws in our school do much harm in life: neglected education; the impracticality of science; not the national form of school." He noted that instead of "dry, unnecessary digging", meaning the uninteresting presentation of the material, the upbringing of the child should be brought to the fore. Particular attention should be paid to individual education, which would take into account the temperament, features, moral and physical inclinations of the child. Richynsky points to the need for the teacher to adapt to the personal characteristics of the child, in this regard relies on the views of Skovoroda. He argues "so that science does not look like mechanical learning, but helps the development of the child and the best inclinations of the child's soul, it should be mentioned Skovoroda "a teacher is not a teacher, but only a servant of nature". Ignoring this testament is the main reason for the moral mutilation of the younger generations" [4].

One of the wrong directions of school education Richynsky saw in the used "impracticality of science". He believed that science should be practical, it "should aim to enable man to fight for existence and to conquer the external nature." To this day, Richynsky noted, "the school filled the heads of students with such knowledge, which was then easily forgotten, replaced by others - those dictated by life. Thus, the first place in the school should be for natural and technical sciences and, of course, with practical nature of training" [4].

According to Richynsky, education should be individual, practical and national. The practical nature of education requires that it be national. The native language at school, Richynsky noted, will not only provide relevant knowledge, but also instill it in the child's soul, laying a solid foundation for the future. The domination of the Moscow region for more than two hundred years drove the native language out of school. It was in the ban on the use of the national language in schools, government and public institutions that he saw the criminal nature of the policy of tsarist Russia, which led to its catastrophe in 1917.

Richinsky also noted that Russia's policy on sanitary needs and the development of medical facilities for the common people was insignificant and had very terrible consequences. He hoped that in an independent Ukrainian state, school education and the 
sanitary situation in the region would be reformed. He believed that the Ukrainian government should pay close attention to the dissemination of medical information among the common people. He noted that "some zemstvos have introduced hygiene and first aid training in schools on their own initiative, care must be taken to ensure that this is not exceptional, but is carried out on a large, national scale" [4].

A. Richynsky, as a physician and teacher, categorically opposed the premature hard physical labor of children. He believed that it was useful for the state for young people to grow strong and hardened, and for this purpose productive reforms should improve the situation of the peasantry and the working class so that there was no need to "spoil the health of children by sending them hard to work". It is poverty and hunger that force parents to send their children to work. In the absence of a foster parent in the family, the child is forced to find employment, it is difficult to work physically when the body is just developing and has not yet strengthened. For the nation to be strong, it is necessary to carry out appropriate reforms at the state level that would improve the lives of peasants and workers, and then there will be no need for premature hard physical child labor, which further adversely affects human health [4].

In his book, Arsen Richynsky managed to present the most important knowledge of hygiene, the acquisition of which provided for the then educational program. This textbook, although written and published in 1919, deserves serious attention from modern medical and pedagogical workers. The book is easy to read and interesting. It is also worth adopting the method of lighting the subject, because the light style and original form of presentation of the material contribute to its assimilation by students.

Conclusions and prospects for further research. Thus, the textbook of the famous socio-political and cultural-educational figure of the first half of the XX century. A. Richynsky's "Hygiene course of health science" is evidence that during the Ukrainian state of 1917-1920, according to the approved educational program of schools and gymnasiums, hygienic education and training was carried out at the appropriate level. The book presents interesting ideas on how to correct the shortcomings of education in Ukrainian schools and gymnasiums that emerged during the Russian Empire. Today, when we have an independent Ukrainian state in which school education is being reformed and improved, when the whole world is facing the difficult challenge of COVID-19, it would be worthwhile to return to the school curriculum such in-depth study of hygiene and emergency care as envisaged by education program for schools and gymnasiums of the UPR period. 


\section{References}

1. Richinsky A. Materials for the study of hygiene: the science of health in the middle classes of high schools and primary schools. 1918. Ukrainian.

2. Richinsky A. Autobiography. 1954 [manuscript]. Volyn Museum of Local Lore. Ukrainian.

3. Richinsky A. Materials for the study of hygiene: the science of health. Part two. 1918. Ukrainian.

4. Richinsky A. Hygiene course: health sciences. Adapted to the program of VII-VIII classes of gymnasiums. 1919. Ukrainian.

5. Andreychin M., Mazur P., Yosyk J. Infectious considerations in the textbook of Arsen Richynsky "Hygiene Course" (1919). // Materials of the IX Richyn readings with international participation "Arsen Richynsky in the life of Zaslavl region and in the context of Ukrainian science". Kremenets, 2017. C. 87-92. Ukrainian.

6. Mazur P. Organization of hygienic education and training of students in schools and gymnasiums of the times of the Ukrainian People's Republic. // Health-preserving technologies of an educational institution in the conditions of modern educational changes: materials of the All-Ukrainian scientific-practical conference. Ternopil, 2019. C. 9-14. Ukrainian. 